PIOTR M. PILARCZYK (Poznań)

\title{
Początki nauk prawno-finansowych w Polsce (do 1918 r.)
}

I. Ostatnie lata przynoszą wzmożone zainteresowanie historycznym rozwojem prawa finansowego $\mathrm{w}$ Polsce ${ }^{1}$. W prowadzonych dociekaniach pomijane są jednakże jego początki, co powoduje, iż powstaje wrażenie, jakby nauka prawa finansowego zaczęła się dopiero wraz z zakończeniem I wojny światowej $^{2}$. Eugeniusz Ruśkowski wprawdzie dostrzegł epokę przed 1918 r., lecz stwierdził, iż historia rozwoju nauki prawa finansowego wiąże się jednak z historią polskiej państwowości. Dlatego jej początkowym etapem określił czas po odzyskaniu niepodległości ${ }^{3}$. Nie wchodząc w polemikę z samym twierdzeniem o powiązaniu nauki prawa $\mathrm{z}$ istnieniem formy politycznej państwa, w którym się ją uprawia, celowe wydaje się przyjrzenie właśnie temu pomijanemu okresowi wcześniejszemu. Nauka prawa finansowego bowiem nie pojawiła się ex nihilo w momencie odrodzenia państwowości w 1918 roku, lecz stanowiła kontynuację tego, co powstało w okresie zaborów.

Jest jednak oczywiste, że kwestie polityczno-państwowe i ich konsekwencje (które w tym miejscu nie będą poruszane) miały przemożny wpływ na rozwój polskiej nauki prawa, czy nauki w ogóle. Próby reform anachronicznej

${ }^{1}$ Efektem są publikacje książkowe, których tematyka zakreślona jest nieraz bardzo obszernie, przykładem: A. Kostecki (red.), Z dziejów katedr skarbowości i prawa skarbowego oraz katedr prawa finansowego $w$ Polsce, Kraków 2010; Osobną kwestią są publikacje przywołujące postaci wybitnych profesorów skarbowości, jak np. C. Kosikowski (red.), Prawo skarbowe i prawo finansowe. Szkoty i uczniowie. Księga dedykowana pamięci Profesora Jerzego Lubowickiego, Białystok 2013; Niektórzy z twórców posiadają własne biografie i omówienia twórczości, jak choćby Roman Rybarski czy Ignacy Czuma. W 2014 r. odbyła się na WPiA UAM konferencja pn. „Magistri Nostri skarbowości i prawa skarbowego w Polsce do 1939 r.”, a wygłoszone tam referaty mają zostać wydane w formie książkowej.

2 J. Harasimowicz, Nauka prawa finansowego w Polsce XX wieku, [w:] A. Kostecki (red.), Prawo finansowe i nauka prawa finansowego na przełomie wieków, Kraków 2000, s. 343.

${ }^{3}$ E. Ruśkowski, Prawo finansowe jako dyscyplina naukowa oraz jej dorobek, [w:] C. Kosikowski (red.), System prawa finansowego, t. I: Teoria i nauka prawa finansowego, Warszawa 2010, s. 437. 
szlacheckiej Rzeczypospolitej zakończyła bowiem katastrofa rozbiorów, i jedynie okres Księstwa Warszawskiego, autonomicznego Królestwa Polskiego i Rzeczpospolitej Krakowskiej dawał względnie korzystne warunki dla uprawiania nauki. Natomiast likwidacja warszawskiego ośrodka akademickiego po powstaniu listopadowym czy zniemczenie (przejściowe) uniwersytetów w Krakowie i Lwowie, musiały odbić się negatywnie na możliwościach jej rozwijania. Dopiero w autonomicznej Galicji powstały sprzyjające warunki, których nie dostawało na pozostałych ziemiach polskich - w Królestwie czy Poznańskiem. Brak normalnych form organizacyjnych, szczupłość środowisk naukowych i szykany wobec polskości - choćby w postaci cenzury - ograniczały możliwości prowadzenia i publikowania wyników badań. Brak własnego państwa również nie zachęcał do zajmowania się kwestiami obowiązującego prawa, które siłą rzeczy musiało być prawem zaborcy ${ }^{4}$.

II. Sfera finansów jest tak dawna jak instytucja państwa, które musiało od samego początku tworzyć normy prawne, aby gromadzić środki materialne na utrzymanie własnego aparatu władzy ${ }^{5}$. Jednak nie oznaczało to jeszcze powstania odrębnego prawa finansowego, które jest młodą gałęzią prawa. Samo pojęcie prawa finansowego jest oczywiście pojęciem współczesnym, które zastąpiło wcześniej używaną nazwę: prawo skarbowe (podobnie zamiast skarbowość, zaczęto używać pojęcia finanse, choć zdarza się powrót do terminu używanego poprzednio ${ }^{6}$ ). Ta terminologiczna zmiana zaszła wraz z wprowadzaniem w Polsce ustroju socjalistycznego, gdy ,dawne wąsko ujmowane prawo skarbowe było niewystarczające” dla wzrastającej działalności finansowej państwa i zakresu jej regulowania przez normy prawne ${ }^{7}$. Współczesne prawo finansowe jako odrębna gałąź prawa ma swoje dylematy, zwiększającą się specjalizację i zmieniający się zakres. Nie wchodząc tu w spory - można przyjąć, że składa się z prawa podatkowego (daninowego) i budżetowego, walutowego, dewizowego i prawa rynku finansowego ${ }^{8}$. Jednak tradycyjnie ujmując, prawo finansowe (skarbowe) reguluje kwestie związane z dochodami i wydatkami państwa oraz budżetem, i od badania takiej problematyki wzięło swój początek.

Tak określony przedmiot regulacji prawa finansowego częściowo pokrywa się z zainteresowaniami ekonomii. Badania makroekonomiczne dotyczące

4 Zob. E. Till, O ubóstwie naszej literatury prawniczej, „Przegląd Sądowy i Administracyjny”, 1890 (Rozprawy i zapiski literackie), s. 63.

5 Z. Fedorowicz, Instytucje finansowe, Warszawa 1965, s. 24.

${ }^{6}$ Zob. np. J. Głuchowski, Wstęp do skarbowości, Poznań 1997, s. 7.

${ }^{7}$ M. Weralski, Instytucje prawno-finansowe a prawo finansowe, [w:] System instytucji prawno-finansowych PRL, t. 1: Instytucje ogólne, red. M. Weralski, Wrocław 1982, s. 31.

${ }^{8}$ C. Kosikowski, Samodzielny byt prawa finansowego jako działu prawa i problem jego autonomiczności, [w:] idem, System prawa finansowego, t. I, s. 419-422. 
gospodarki państwowej obejmują również takie kwestie jak dochody i wydatki budżetowe czy system walutowy. Raczkująca ekonomia wykładana była na ziemiach polskich w ramach wydziałów prawa, i choć obecnie podejście prawników i ekonomistów do tych samych problemów jest różne, to jeszcze w okresie międzywojennym częste było, że ten sam profesor wykładał zarówno ekonomię (polityczną), jak i prawo skarbowe. Osoby uważane za prekursorów polskiej skarbowości były również ekonomistami. Widać to nie tylko w ich działalności naukowej, ale również dydaktycznej. Postaci z historii ekonomiki są również postaciami z historii nauki prawa finansowego ${ }^{9}$. Już Stanisław Głąbiński dostrzegał, że „ekonomika i nauka skarbowa tak rozwojem historycznym jak treścią [są] ściśle ze sobą związane" ${ }^{10}$, a i obecnie można spotkać się z opinią, że ,[r] [efleksje prawników i ekonomistów nakładały się na siebie tak dalece, iż w zasadzie nie sposób ich rozdzielić" "11. Pomimo prób wprowadzenia rozdziału nauki finansów o charakterze ekonomicznym od nauki prawa finansowego, o charakterze prawnym, do tej pory zresztą często, czy to w tytułach podręczników, czy w nazwach wykładów, łączy się dwa elementy: finanse i prawo finansowe. Skoro finanse publiczne pozostają pod wpływem trzech powiązanych ze sobą czynników: gospodarki, polityki oraz prawa $^{12}$, niezwykle trudno w sposób ścisły oddzielić od siebie te elementy.

Te oczywiste związki prawa i ekonomii, zbiegających się w przedmiocie finansów publicznych, nie ułatwiają analizy początków nauki prawa finansowego. Rozróżnienie tego, co zaliczymy do jednej lub drugiej z nauk, może być problematyczne. Tym bardziej, że byłoby to nakładaniem współczesnych pojęć na twórczość, która tych podziałów jeszcze nie znała.

Zainteresowanie skarbowością, a zwłaszcza podatkami wśród ekonomistów jest bezsporne; można niewątpliwie uznać ich za tych, którzy pierwsi się zajęli tą problematyką. Przyjmując, że sama nowoczesna nauka ekonomii jak wielu historyków myśli ekonomicznej uważa - ukształtowała się dopiero w II połowie XVIII wieku dzięki Adamowi Smithowi ${ }^{13}$, dostrzec można, że zwłaszcza w Anglii i Francji, począwszy od końca XVIII w., zagadnienie gospodarki finansowej państwa stanowiło część klasycznej ekonomii politycznej. Odmienne podejście zaznaczyło się szczególnie w nauce niemieckiej, gdzie kameraliści zajęli się szeregiem praktycznych aspektów funkcjonowa-

9 Zob. np. S. Głąbiński, Historia ekonomiki, t. II: Historia ekonomiki polskiej, Lwów 1939.

${ }^{10}$ Idem, Pojęcie nauki skarbowej, Sambor 1889, s. 3.

11 J. Sobiech, Finanse publiczne jako nauka ekonomiczna, [w:] Nauka finansów publicznych i prawa finansowego w Polsce. Dorobek i kierunki rozwoju. Księga jubileuszowa profesor Alicji Pomorskiej, Lublin 2008, s. 47.

12 Zob. R. Mastalski, E. Fojcik-Mastalska (red.), Prawo finansowe, wyd. 2, Warszawa 2013, s. 25-39; E. Ruśkowski, Nauka finansów i nauka prawa finansowego, [w:] A. Kostecki (red.), Prawo finansowe i nauka prawa finansowego na przetomie wieków, Kraków 2000, s. 370.

13 Por. J. Chodorowski, Adam Smith (1723-1790). Życie i dzieto autora „Badań nad natura i przyczynami bogactwa narodów", Wrocław 2002, s. 277-284. 
nia państwa, w tym również jego finansami ${ }^{14}$. Skarbowość wchodziła tam w zakres ówczesnej nauki o państwie (Staatwissenschaft), którą w polszczyźnie nazywano zazwyczaj umiejętnościami politycznymi. W ramach tej nauki, wraz z jej rozwojem i ewolucją samej instytucji państwa, podejście do skarbowości zaczęło się zmieniać i zaczęto traktować ją odrębnie.

Wyodrębnienie samego prawa finansowego (skarbowego) jest jeszcze późniejsze. „Badania naukowe nad prawem skarbowości, mogły powstać dopiero w prawdziwym państwie nowożytnym”, pisał Józef Bohdan Oczapowski $^{15}$. Oczywiście, jak wspomniano już wyżej, przez całe wieki istniały normy regulujące kwestie podatkowe, ale powstanie odrębnej gałęzi prawa możliwe było wraz z upodmiotowieniem społeczeństwa, z przejściem od relacji „władca - poddany” do relacji ,państwo - obywatel”. Jako część prawa publicznego wyodrębniło się ono z prawa konstytucyjnego i administracyjnego ${ }^{16}$. Jednak jeszcze w II poł. XIX w. pisano o skarbowości jako takiej, i wliczano do niej wszelkie urządzenia, takie jak ustawy, rozporządzenia, władze administracyjne czy urzędy wszelkiego rodzaju ${ }^{17}$. Po wyodrębnieniu samej skarbowości, później następowało wyodrębnianie z niej prawa skarbowego.

III. W okresie szlacheckiej Rzeczypospolitej brak było jeszcze zarówno możliwości, ale i rzeczywistej potrzeby rozwoju nauki prawa skarbowego. I to pomimo, iż literaturę poruszającą kwestie ekonomiczno-polityczne znaleźć można przez cały czas istnienia tego państwa ${ }^{18}$. Bezsprzecznie wraz z rosnącą świadomością konieczności zmian ustrojowych od schyłku epoki saskiej zaczęto żywiej interesować się finansami państwowymi, a okres reform stanisławowskich przyniósł w skarbowości wiele zmian. W tym okresie zaczęto również zajmować się naukowo ekonomią, wykładając ją w sposób nowoczesny (tj. fizjokratyczny) i tworząc pierwsze katedry ekonomii politycznej (Kraków 1780, Wilno 1782). I choć prace ówczesnych ekonomistów W różnym stopniu dotyczyły zagadnień finansowych, choć zajmowali się oni szeregiem problemów, które wchodziły w zakres regulacji prawnej (przede wszystkim podatkami i innymi dochodami państwa), nie powstała wówczas jeszcze naukowa refleksja nad skarbowością. Jeden $\mathrm{z}$ najznamienitszych polskich przedstawicieli tej nauki w XVIII w., Jan Ferdynand Nax, w wielu pismach rozwodził się nad podatkami w Rzeczypospolitej, lecz czynił to

14 Por. M. Weralski, Pojęcie i funkcje finansów w literaturze burżuazyjnej, „Finanse” 1965, nr 3, s. 38-41.

15 J.B. Oczapowski, Celniejsi pisarze umiejętności skarbowej. Rzut oka na rozwój tej nauki, jako szkic do napisania jej historii, Warszawa 1868, s. 30.

${ }^{16}$ C. Kosikowski, J. Matuszewski, Geneza i ewolucja oraz stan obecny i przewidywana przyszłość prawa finansowego, [w:] C. Kosikowski, System prawa finansowego, t. I, s. 28-29.

${ }^{17}$ K.H. Rau, Zasady umiejętności skarbowej, t. I, Kraków 1865, s. 1-2.

18 Por. E. Lipiński, Historia polskiej myśli społeczno-ekonomicznej do końca XVIII wieku, Wrocław 1975. 
z punktu widzenia powodzenia gospodarczego kraju, a nie prawnej regulacji ${ }^{19}$. Nawet pierwsze próby budżetowe w Rzeczypospolitej nie spowodowały powstania piśmiennictwa na ten temat ${ }^{20}$.

Wprowadzenie na ziemiach polskich naukowego podejścia do skarbowości wiązać należy z reformami uniwersytetów na zagarniętych przez Austrię terenach Rzeczypospolitej. Wprowadzano bowiem, najpierw we Lwowie, potem w Krakowie, wzorem zagranicznych uniwersytetów, przedmiot nazywany umiejętnościami politycznymi (często nazywany był również kameralistyką czy nauką policji). Przedmiot, o charakterze wyraźnie usługowym wobec potrzeb biurokratycznego państwa nowożytnego, obejmował całe spektrum zagadnień związanych $\mathrm{z}$ ustrojem, polityką, administracją, gospodarką oraz finansami państwa. Jeszcze w końcu XVIII w. powstała na Uniwersytecie Lwowskim Katedra Umiejętności Politycznych, co jednak zbiegło się z germanizacją tej uczelni. Natomiast w $1801 \mathrm{r}$. taką katedrę wyodrębniły władze austriackie na krakowskiej wszechnicy ${ }^{21}$.

W Krakowie zlikwidowaną w czasach Księstwa Warszawskiego katedrę przywrócono w 1817 r. jako jedną z katedr Wydziału Prawa. Program wykładu nauk administracyjnych z 1831 r., który stworzył starający się o stanowisko Ferdynand Kojsiewicz, obejmował całe spektrum zagadnień prawnych i ekonomicznych, wśród nich była również „nauka skarbowa, czyli finansowa". Zwięzły konspekt nie pozwala na wyciąganie daleko idących wniosków, ale wydaje się, że zamiarem Kojsiewicza były objęcie problemów zarówno ekonomicznych, jak i prawnych ${ }^{22}$.

W Warszawie z kolei w 1808 r. powstała Szkoła Prawa, a w 1811 r. Szkoła Nauk Administracyjnych, które stanowiły zaczyn pod przyszły uniwersytet ${ }^{23}$. Najpierw ks. Franciszek Ksawery Szaniawski, a od 1812 r. Dominik Krysiński prowadzili tam wykłady z ekonomii politycznej ${ }^{24}$. Ten ostatni, wybitny ekonomista, zajmował się jednak finansami jako jej elementem ${ }^{25}$. W czasach Królestwa Polskiego, gdy funkcjonował już w Warszawie uniwersytet, wykłady przejął Fryderyk Skarbek. Plan zajęć z 1821 r. dla kierunku administracja

19 J.F. Nax, Wybór pism, Warszawa 1956, passim.

${ }^{20}$ Por. P.M. Pilarczyk, Początki instytucji budżetu państwa w Polsce, Poznań 2014, s. 66-107 .

${ }^{21}$ M. Patkaniowski, Dzieje Wydziatu Prawa Uniwersytetu Jagiellońskiego od reformy koltatajowskiej do końca XIX stulecia, Kraków 1964, s. 81-82.

22 J. Malec, O początkach Katedry Umiejętności Politycznych Uniwersytetu Jagiellońskiego, Kraków 2009, passim.

${ }^{23}$ S. Kieniewicz (red.), Dzieje Uniwersytetu Warszawskiego 1807-1915, Warszawa 1981, s. $14-20$.

24 A. Rosner, Dzieje Wydzialu Prawa Uniwersytetu Warszawskiego w latach 1808-1831, [w:] G. Bałtruszajtys (red.), Zarys dziejów Wydziału Prawa i Administracji Uniwersytetu Warszawskiego, Warszawa 2008, s. 24, 26.

25 Zob. D. Krysiński, O ekonomii politycznej, [w:] idem, Wybór pism, Warszawa 1956, s. 32-35. 
obejmował nie tylko ekonomię polityczną, ale i wykład z przedmiotu „nauka administracji i finansów"26.

Zlikwidowany w 1831 r. Uniwersytet Wileński posiadał od 1782 r. jedynie katedrę ekonomii politycznej. Wykładający na niej, mimo nieraz wybitnych osiągnięć w dziedzinie ekonomii (Hieronim Stroynowski), nie zajmowali się kwestiami skarbowymi ${ }^{27}$.

W tym okresie wydane zostają również dwie niewielkie prace dotyczące skarbowości. Autorem pierwszej jest Feliks Słotwiński, który nie był ekonomistą, a profesorem na wydziale prawa uniwersytetu krakowskiego. Naukowo zajmował się innymi kwestiami, przede wszystkim prawem natury, i tylko przejściowo wykładał ekonomię polityczną, czego wynikiem była oparta na nauce niemieckiej i wydana w 1818 r. książka $O$ istotnych zasadach nauki skarbowey ${ }^{28}$. Zdefiniował tam „Naukę skarbową czyli Finansyą”, jako część „umiejętności politycznych”, której przedmiotem jest najkorzystniejsze wybieranie dochodów krajowych na zaspokojenie potrzeb publicznych ${ }^{29}$. W krótkim dziele objaśniał, co to jest plan finansowy (czyli budżet) oraz zajmował się dochodami państwowymi, w szczególności podatkami. Dzieło, jak można wnosić z końcowych zdań, kierował do „Reprezentacyi kraiowey”, czyli miało stanowić przewodnik dla członków Zgromadzenia Reprezentantów Rzeczpospolitej Krakowskiej.

O ile praca Słotwińskiego uważana jest za pozbawioną większej wartości kompilację, zazwyczaj inaczej ocenia się dzieło Fryderyka Skarbka ${ }^{30}$. Uważany za najbardziej znanego polskiego ekonomistę I połowy wieku XIX ${ }^{31}$, po niefortunnym tłumaczeniu pracy Karola Ganilha ${ }^{32}$, w 1824 r. opublikował Rys ogólny nauki finansów. Oparte o najlepszą literaturę, wzbogacone oryginalnymi poglądami dzieło Skarbka, było jednak adresowane „li tylko do studentów" jego wykładów, i - jak sam autor zaznacza - stanowiło jedynie dopełnienie prowadzonych prelekcji.

${ }^{26}$ A. Rosner, op. cit., s. 34, 37.

27 Zob. J. Bieliński, Uniwersytet Wileński (1579-1831), t. II, Kraków 1899-1900, s. 6-7, 11, 505-518; W. Giza, Narodziny polskiej myśli ekonomicznej w ośrodku wileńskim, „Zeszyty Naukowe Akademii Ekonomicznej w Krakowie”, 2001, nr 585, s. 107-119.

${ }^{28}$ K. Opałek, U schyłku szkoty prawa natury - Feliks Stotwiński (1788-1863), [w:] M. Patkaniowski (red.), Studia z dziejów Wydziału Prawa Uniwersytetu Jagiellońskiego, Kraków 1964, s. 99.

${ }^{29}$ F. Słotwiński, O istotnych zasadach nauki skarbowey, Kraków 1818, s. 4-5.

${ }^{30}$ Z. Fedorowicz, op. cit., s. 170-171. W literaturze można jednak znaleźć również bardziej krytyczne opinie.

31 J. Górski, Zarys historii ekonomii politycznej, wyd. 2, Warszawa 1984, s. 207.

${ }^{32} \mathrm{~K}$. Ganilh, $O$ dochodzie publicznym ludów starożytnych, srzedniego wieku i nowoczesnych a w szczególności Francyi i Anglii. Od srzodka 15go aż do 19 go wieku, t. 1-2, Warszawa 1816. J. Oczapowski nazwał pracę „ramotą”, która nie przynosi zaszczytu szkole francuskiej (J.K. Rau, op. cit., s. XIII). Sam Skarbek wspominał, że przekład „mozolny i nudny” powstał z inspiracji Stanisława Zamoyskiego, a praca ta „żadnego praktycznego użytku dla kraju naszego nie miała”, $P a$ miętniki Fryderyka hrabiego Skarbka, wyd. P. Mysłakowski, Warszawa 2009, s. 144. 
Adolf Suligowski w swej bibliografii prawniczej wylicza obie prace, Słotwińskiego i Skarbka, jako dzieła dotyczące prawa finansowego ${ }^{33}$. Trudno się z tym zgodzić, bo są to prace, w których o prawie nie ma właściwie mowy. Słotwiński przedstawia bowiem nie urządzenie skarbowości w Rzeczpospolitej Krakowskiej (czy jakimkolwiek innym kraju - ,[...] stąd bynaymniey wnosić nie można iakoby wyszczególnione przezemnie podatki w kraiu naszym lub innym istnąć powinny [...]"34), ale przez „zasady nauki skarbowej” rozumie rodzaje podatków i zasady podatkowe. Podział zresztą na teorię skarbowości i pozytywne, obowiązujące prawo skarbowe jest późniejszy - na gruncie austriackim przeprowadzony od połowy lat 50. XIX w. ${ }^{35}$

Również dzieło Skarbka klasyfikowane bywa otwarcie jako ekonomicz$\mathrm{ne}^{36}$, co wydaje się słuszne. Sam autor uważał je jedynie za element pracy nad swoim ekonomicznym opus magnum o gospodarstwie narodowym ${ }^{37}$. Praca nie zawiera odniesień do istniejącego prawa, stanowi teoretyczne rozważania ekonomiczne o rodzajach dochodów i wydatków publicznych.

Gdy oba pierwsze polskie dzieła o skarbowości nie dotyczą prawa skarbowego, w tym samym czasie Wawrzyniec Mirecki opublikował w trzech częściach w „Dekadzie Polskiej” artykuł „O prawodawstwie i administracyj finansowej". W tej krótkiej pracy, która w dużej mierze ma (podobnie jak wyżej wymienione) charakter ekonomiczny, autor prawdopodobnie po raz pierwszy na gruncie polskim rozróżnił oraz zdefiniował prawo finansowe i administrację finansową. „Działania władzy prawodawczej, ile ściągają się do własności publicznej, zowią się prawodawstwem finansowym", a ustawy finansowe podają ,zasady do oznaczenia i zabespieczenia dochodów publicznych, a oraz rostropnego kierowania wydatkami publicznemi" ${ }^{38}$.

IV. Kolejne dziesięciolecia nie przyniosły praktycznie dalszych badań nad skarbowością ${ }^{39}$. Sytuacja zmieniła się dopiero z nastaniem lat 60 ., gdy liberalizacja polityki caratu i przywrócenie Warszawie uczelni wyższej, a w zaborze austriackim stworzenie autonomii galicyjskiej, przywróciło możliwość prowadzenia naukowej refleksji nad tymi zagadnieniami. W kolejnych latach, aż do I wojny światowej, zainteresowanie skarbowością wzrastało, przyno-

33 A. Suligowski, Bibljografia prawnicza polska XIX i XX wieku, Warszawa 1911, s. 190.

${ }^{34}$ F. Słotwiński, op. cit., s. 53-54.

${ }^{35}$ M. Patkaniowski, op. cit., s. 411.

36 J. Górski, op. cit., s. 207; Z. Fedorowicz, op. cit., s. 170.

${ }^{37}$ F. Skarbek, Pisma ekonomiczne, Warszawa 1936, s. 302.

38 W. Mirecki, O prawodawstwie i administracyi finansowej, „Dekada Polska”, 4/1821, s. 149-150 .

39 Pojawiły się w tym okresie jedynie pojedyncze prace, w większości o charakterze historycznym. Ciekawostkę stanowi książka hr. Józefa Łubieńskiego, System wolnego handlu i podatkowania, Lipsk 1848, gdzie autor przedstawione przez siebie koncepcje próbuje zastosować do aktualnego (1847) budżetu Prus. 
sząc oprócz prac teoretycznych również szereg prac praktycznych, dotyczących szczegółowych rozwiązań prawa podatkowego.

Rozwijanie badań nad skarbowością następowało w zmienionych okolicznościach. W trakcie owej przerwy trwającej od lat 30 . zachodziły poważne zmiany w nauce, zwłaszcza niemieckiej. Dawne szerokie „umiejętności polityczne" zaczynały dzielić się na specjalistyczne, szczegółowe zagadnienia. Jednak jako takim starano się nadać im status nauki odrębnej od prawa i ekonomii ${ }^{40}$. Jeszcze w latach 60. środowisko krakowskie wydawało „Czasopismo poświęcone prawu i umiejętnościom politycznym", a owe umiejętności polityczne odpowiadały z grubsza współcześnie rozumianym problemom administracji i prawa publicznego. W pierwszych numerach „Przeglądu Sądowego i Administracyjnego" krakowski profesor Franciszek Kasparek pisał o zmarginalizowaniu nauczania umiejętności politycznych w programach ówczesnych studiów prawniczych. Kontrastowało to z bujnym rozkwitem tych nauk i ich coraz większą specjalizacją. Wśród wielu wyodrębnionych dziedzin pojawia się również skarbowość ${ }^{41}$.

$\mathrm{Na}$ uniwersytecie krakowskim dostrzegano ową coraz większą specjalizację poszczególnych dyscyplin wchodzących w skład umiejętności politycznych. Od 1849 r. Wydział Prawa ponawiał próby ich rozdzielenia, ale długo nie przynosiło to rezultatów. Natomiast od roku 1850/51 wykładano tam osobno austriackie prawo finansowe. Pozytywne prawo finansowe, które nie posiadało odrębnej katedry, uważano wówczas za fragment prawa administracyjnego, gdy tymczasem naukę skarbowości traktowano wciąż jako część umiejętności politycznych ${ }^{42}$.

W Warszawie wraz z reformami Wielopolskiego przywrócono na kilka lat (1862-1869) uniwersytet, działający pod nazwą Szkoły Głównej. W jej strukturze znalazł się również Wydział Prawa, a w jego ramach Katedra Umiejętności Politycznych. Wykładano tam również ekonomię, a od 1865 r. istniała osobna Katedra Skarbowości i Ustawodawstwa Skarbowego, gdzie wykład z tej materii prowadził Józef Oczapowski ${ }^{43}$. I choć dydaktykiem był słabym (studenci w Warszawie skarżyli się na niezrozumiałość wykładów, podobnie niepopularny był później w Krakowie, gdzie przeniósł się po likwidacji Szkoły Głównej), to jednak - mimo krytyki współczesnych - należy zauważyć jego znaczne osiągnięcia naukowe $\mathrm{e}^{44}$.

40 A. Białecki, Tłomacz do czytelnika, [w:] Roberta Mohla Encyklopedja Umiejętności Politycznych, t. I, Warszawa 1864, s. VI.

${ }^{41}$ F. Kasparek, O nauce umiejętności politycznych, „Przegląd Sądowy i Administracyjny”, 1876, s. 23-25, 33-34.

42 M. Patkaniowski, op. cit., s. 297-299, 411-412.

43 M. Paszkowska, Wydział Prawa i Administracji Szkoty Głównej Warszawskiej w latach 1862-1869, [w:] G. Battruszajtys (red.), op. cit., s. 64, 69-70.

${ }^{44}$ S. Konarski, Oczapowski Józef Bohdan, PSB, t. XXIII, s. 521-522. 
Wkład Oczapowskiego w odnowienie zainteresowania problematyką skarbową jest znaczny. W 1865 r. rozpoczynając wówczas swą karierę naukową, przełożył z języka niemieckiego pracę Karola Henryka Raua Zasady umiejętności skarbowej. Jako tłumacz krytycznie odniósł się do dotychczasowych polskich osiągnięć naukowych w tej dziedzinie, i już we wstępie nazwał krótkie prace Słotwińskiego i Skarbka „pisemkami”. Właśnie wyraźny brak prac o skarbowości stał za - jak przekonywał - koniecznością przybliżenia pracy Raua. Oczapowski zauważył również rozwój, który przeżywały „specyalne gałęzie Umiejętności Państwa" w nauce niemieckiej, a które warte były oddzielnych studiów.

Oczapowski nie był bezkrytycznym tłumaczem, a przybliżając pracę niemieckiego ekonomisty, w szeregu obszernych przypisów wchodził z autorem w polemikę. W tym samym czasie rozpoczął zresztą własną twórczość naukową, jeszcze w Warszawie publikując zwięzłe studium rozwoju i współczesnego stanu nauki skarbowości ${ }^{45}$. Dalsze jego prace ukazywały się już w Krakowie, choć trzeba zauważyć, że z czasem poszerzył on znacznie spektrum swoich zainteresowań, porzucając tematy stricte skarbowe.

V. Wraz z rozwojem nauki skarbowości powoli również rozszerzały się jej ramy organizacyjne. Choć w Krakowie wykład prawa finansowego istniał już wcześniej, to dopiero u schyłku wieku XIX udało się wyodrębnić w uniwersyteckiej strukturze skarbowość, tworząc na Wydziale Prawa Uniwersytetu Jagiellońskiego Katedrę Skarbowości i Prawa Skarbowego pod kierownictwem Juliusza $\mathrm{Leo}^{46}$. Na Uniwersytecie Lwowskim wykład i katedrę powołano wcześniej, bo już w latach 30., lecz przed nastaniem okresu autonomicznej Galicji trudno rozważać ją w kategoriach polskiej nauki, tym bardziej, gdy wykładający tam początkowo Czech Maurycy Chlupp zajmował się podatkami austriackimi ${ }^{47}$.

Po epizodzie Szkoły Głównej, w miejsce zlikwidowanego uniwersytetu polskiego istniała w Warszawie, aż po ewakuację w 1915 r., uczelnia rosyjska. Choć zdarzało się, że wykładający tam profesorowie mieli spore naukowe osiągnięcia, a nawet zajmowali się w swych badaniach zagadnieniami polskimi $^{48}$, to nie dotyczyło to problematyki finansów.

Pierwszy polski systematyczny wykład skarbowości wyszedł spod pióra Leona Bilińskiego w 1876 r. Dla autora była to kontynuacja wcześniejszego Wykładu Ekonomii Społecznej. Sam stwierdzał, że oba dzieła składają się na jedną naukę, czyli ekonomię polityczną. Potrzeba wydania podręcznika wyni-

45 J. Oczapowski, op. cit.

46 Z dziejów katedr..., s. 19.

47 L. Finkel, S. Starzyński, Historya Uniwersytetu Lwowskiego, Lwów 1894, s. 246, 254.

48 Zob. A. Bosiacki, Wydziat Prawa Cesarskiego Uniwersytetu Warszawskiego $w$ latach 1869-1915, [w:] G. Bałtruszajtys (red.), op. cit., passim. 
kała z dotychczasowego braku takowego w języku polskim ${ }^{49}$. Autor korzystając obficie z nauki niemieckiej, podzielił pracę na trzy części: wydatki skarbowe, dochody skarbowe i bilans skarbowy. Oprócz teorii, Biliński przedstawił aktualne regulacje prawne obowiązujące w skarbowości austriackiej.

$\mathrm{Na}$ kolejne tego typu ogólne dzieło czekać było trzeba bez mała 20 lat. W tym okresie wydano jedynie tłumaczenie pracy włoskiego ekonomisty Luigiego Cossy „Początki [tj. wstęp do - przyp. PMP] nauki finansów”. Tłumacz, Józef Budkiewicz (nb. klasyfikujący za autorem tłumaczonego dzieła skarbowość jako część ekonomii), wyjaśniał, że spolszczona przez Oczapowskiego praca Raua jest już zdezaktualizowana, a sama praca Bilińskiego to mało, gdy „nasz ruch naukowy w zakresie nauki finansów” jest po prostu „słaby”.

Autorem drugiej polskiej syntezy skarbowości był Stanisław Głąbiński, podobnie jak Biliński również profesor uniwersytetu lwowskiego. Głąbiński zajmował się ekonomią społeczną, i dopiero od $1891 \mathrm{r}$. jego veniam legendi rozszerzona została na skarbowość dzięki pracy Pojęcie nauki skarbowej" ${ }^{51}$. W tej krótkiej rozprawie próbował określić genezę i miejsce rodzącej się skarbowości w ramach nauki ${ }^{52}$. Kilka lat później, w 1894 r., ukazuje się jego synteza: Wykład nauki skarbowej ${ }^{53}$, która zawiera w rzeczywistości, poza obszernymi rozważaniami historycznymi, szeroki wykład dotyczący rodzajów dochodów, zwłaszcza podatków, i wydatków, wraz ze spinającym je budżetem. Są to jednak rozważania teoretyczne, nieoparte o żaden pozytywny system prawny.

Dopiero z czasem to teoretyczne nastawienie uległo zmianie. W $1911 \mathrm{r}$. ukazało się trzecie wydanie dzieła Głąbińskiego, pn. Nauka skarbowości z dodatkiem o skarbowości Austrii i Galicji ${ }^{54}$, gdzie zostało już uwzględnione pozytywne prawo skarbowe.

Przed zakończeniem I wojny światowej, w 1917 r., zdążył jeszcze ukazać się podręcznik Henryka Radziszewskiego (jego kolejne wydanie opublikowano w 1919 r.) pt. Nauka skarbowości. Wykład skarbowości państwowej i gminnej. Czerpiąc z literatury francuskiej i niemieckiej, autor thumaczył, że publikacja jest zapisem wykładów wygłoszonych na Kursach Akademickich Wyższej Administracji w Warszawie i - w odróżnieniu od pracy Głąbińskiego - stanowi wyraz idei solidaryzmu narodowego, któremu hołdował. Największa część książki poświęcona jest podatkom i innym dochodom, przy czym oprócz rozważań teoretycznych przedstawione są współczesne regula-

${ }^{49}$ L. Biliński, System nauki skarbowej a w szczególności nauki o podatkach, Lwów 1876, s. V.

${ }^{50}$ L. Cossa, Poczatki nauki finansów, Warszawa 1884, s. 5-7.

51 L. Finkel, S. Starzyński, op. cit., s. 221.

52 S. Głąbiński, op. cit.

${ }^{53}$ Idem, Wykład nauki skarbowej, Lwów 1894.

${ }^{54}$ Idem, Nauka skarbowości z dodatkiem o skarbowości Austrii i Galicji, wydanie trzecie przerobione, Lwów 1911. 
cje prawne obowiązujące w państwach zaborczych oraz historia rozwiązań polskich. To spojrzenie w przeszłość nie dziwi, gdy Radziszewski zauważa, że będąc świadkami powstawania niepodległej ojczyzny, ,podwaliną każdego niezawisłego bytu państwowego jest dobrze zorganizowana skarbowość" 55 .

Równie skromnie, jak w przypadku wspomnianych, systematycznych wykładów, przedstawiony okres prezentuje się, gdy spojrzeć na monografie dotyczące problematyki skarbowej. Pomimo to, niektóre z nich należy uznać za wyróżniające. Zaczęto wydawać zarówno prace teoretyczne, ale i zajmujące się prawem pozytywnym, w tym prawno-porównawcze.

Taki właśnie porównawczy charakter ma rozprawa, na podstawie której habilitował się Juliusz Leo ${ }^{56}$. Nie tylko zestawił w niej ustawodawstwo dziesięciu państw dotyczące podatku od spadków, ale przedstawił poglądy ekonomistów na ów podatek, a także zawarł własne do niego podejście i projekt reformy.

Równie ciekawa, choć o zupełnie innym charakterze, jest praca Romana Rybarskiego, w okresie międzywojennym prominentnego polityka endeckiego, w nauce znanego bardziej ze swej twórczości ekonomicznej i historycznej. Jednakże Rybarski zaczynał swą karierę uniwersytecką od skarbowości, do której potem zresztą z rzadka powracał. Natomiast jeszcze w 1916 r. wydał teoretyczną pracę pt. Prawno-skarbowe podstawy ustroju państw zwiąkowych, unii i autonomii państwowych. Prezentując w niej dawne i współczesne związki państw, przedstawił problem rozgraniczenia finansów wspólnych i odrębnych w takich organizmach ${ }^{57}$.

Ów skromny dorobek nauki skarbowości w formie osobnych monografii nie oznaczał nikłości zainteresowań tą problematyką. Nastąpił bowiem wysyp artykułów - jeśli porównać to z okresem poprzednim. Choć brak było czasopisma, którego profil odnosiłby się wyłącznie do skarbowości, tym niemniej poszczególne tytuły zamieszczały rozprawy z tej dziedziny. Robiły tak nie tylko pisma prawnicze i ekonomiczne, ale i pisma o charakterze ogólnym zarówno mające charakter naukowy (np. „Biblioteka Warszawska”), jak i popularny.

W czasopismach takich jak „Ekonomista” (właściwie trzech kolejnych pismach o takim tytule) znaleźć można szereg rozpraw dotyczących skarbowości, zarówno współczesnej, jak i historycznej. W szczególności były to rozprawy dotyczące budżetu, czy też podatków i ich reform. W roczniku 1879 r.

${ }^{55}$ H. Radziszewski, Nauka skarbowości. Wykład skarbowości państwowej i gminnej, Warszawa 1917 , s. II-III.

56 J. Leo, Podatek od spadków w teoryi i praktyce państw europejskich, Kraków 1891.

${ }^{57}$ R. Rybarski, Prawno-skarbowe podstawy ustroju państw zwiąkowych, unii $i$ autonomii państwowych, Warszawa 1916; J. Chodorowski, Roman Rybarski (1887-1942). Z historii polskiej myśli ekonomicznej i prawnoustrojowej pierwszej połowy XX wieku, Wrocław 1997, s. 231. 
wydrukowane zostały materiały wzięte z pracy Jana Blocha o finansach Królestwa Polskiego.

Z kolei ówczesne czasopisma prawnicze („Przegląd Prawa i Administracji”58, „Gazeta Sądowa Warszawska”) zamieszczały szereg artykułów dotyczących bieżących kwestii podatkowych.

Można zauważyć, że to właśnie problematyka podatkowa dominowała ilościowo w ówczesnej rzeczywistości. Cały szereg prac dotyczyło prawa podatkowego i zmian w nim zachodzących. Odnosiły się one zwłaszcza do Galicji, ale zajmowano się również przepisami obowiązującymi na ziemiach byłego Królestwa Polskiego. Pojawiły się także prace o charakterze popularnym, mające charakter poradników podatkowych ${ }^{59}$. Szereg prac o walorze praktycznym dotyczyło też zagadnień celnych. Zaczęły ukazywać się również drukiem zbiory obowiązujących przepisów i poszczególne ustawy. W przypadku tych ostatnich, jeśli chodzi o tereny zaboru rosyjskiego, istotne było to, że tym samym tłumaczono je na język polski.

O budżecie i instytucjach budżetowych pisano zazwyczaj w kontekście aktualnych rozwiązań $^{60}$, dlatego na wyróżnienie zasługuje drukowana w odcinkach w „Przeglądzie Polskim” praca krakowskiego profesora Józefa Milewskiego Budżet i kredyt publiczny ${ }^{61}$. Powołując się na współczesną, zagraniczną literaturę przedmiotu przedstawił teoretyczne rozważania dotyczące kwestii budżetowych, oparte o liczne przykłady poszczególnych państw. Inne, drobne drukowane wówczas prace poruszające podobne kwestie przedstawiały aktualne problemy budżetowe lub wręcz prezentowały konkretne ustawy skarbowe (budżetowe).

Oprócz tego pojawiło się silne zainteresowanie tematyką historyczno-finansową. Wówczas ukazała się pierwsza monografia historyczno-skarbowa pióra księcia Tadeusza Lubomirskiego ${ }^{62}$, a historyk Adolf Pawiński zajął się skarbowością czasów Stefana Batorego ${ }^{63}$. Poza licznymi pracami drobnymi, to właśnie w tym okresie powstały do dziś podstawowe, choć oczywiście przestarzałe, dwutomowe opracowania skarbowości Królestwa Polskiego (Henryka Radziszewskiego) oraz Księstwa Warszawskiego (Stanisława

58 Wcześniej „Przegląd Sądowy i Administracyjny”, zob. S. Milewski, A. Redzik, Themis $i$ Pheme. Czasopiśmiennictwo prawnicze w Polsce do 1939 roku, Warszawa 2011, s. 113.

59 Taki charakter ma np. drobna praca F. Szymusika, Reforma podatkowa. Cz. 1, O powszechnym podatku zarobkowym, Lwów 1897, objaśniająca reformę podatkową, wchodzącą w życie z dniem 1 stycznia 1898 r. w Austrii, ,dlatego kontrybuenci powinni się z nią zapoznać dokładnie we własnym interesie przynajmniej w głównych zarysach. Zadanie powyższe ma im ułatwić nasza praca", s. 9.

${ }^{60}$ Zob. J. Michalski, Przegląd najnowszej literatury polskiej z dziedziny skarbowości pod zaborem rosyjskim, „Przegląd Prawa i Administracji”, 1908, s. 873-895.

${ }^{61}$ Opublikowana potem osobno: J. Milewski, Budżet i kredyt publiczny. Roztrzasania finansowe i polityczne, Kraków 1898.

${ }_{62}$ T. L[ubomirski], Trzy rozdziały z historyi skarbowości w Polsce 1507-1532, Kraków 1868.

${ }^{63}$ A. Pawiński, Skarbowość w Polsce i jej dzieje za Stefana Batorego, Warszawa 1881. 
Żółtowskiego) ${ }^{64}$. Po części charakter historyczny ma trzytomowe dzieło Jana Blocha o finansach Rosji, z których tom trzeci dotyczy finansów Królestwa Polskiego od momentu powstania tego państwa ${ }^{65}$.

VI. Bujny rozkwit nauki prawa finansowego nastąpił po odzyskaniu niepodległości w 1918 r., co było możliwe właśnie dzięki osiągnięciom wcześniejszego okresu. Po trudnych początkach, począwszy od lat 60. XIX wieku pojawiło się zainteresowanie problemami finansowymi państwa, czego efektem była wzrastająca ilość publikacji oraz instytucjonalizacja prawa skarbowego na jedynych wówczas polskich wydziałach prawa, w Krakowie i Lwowie.

Podwaliny zostały położone, i dzięki rozwojowi nauki prawa finansowego przed 1918 r. wykształcono odpowiednie kadry naukowe, które później brały udział w tworzeniu i kierowaniu finansami państwa, zajmowały się prawem finansowym odrodzonej Rzeczypospolitej. Kadra ta również zasilała nowo tworzone ośrodki naukowe, które stawały się nowymi miejscami badań nad prawem finansowym.

\section{THE BEGINNING OF THE LEGAL AND FINANCIAL SCIENCE IN POLAND (BEFORE 1918)}

\section{Summary}

The article focuses on the beginnings of financial law in Poland before 1918 . All previous studies have focused on the developments in that branch of law in the post-1918 period, ignoring its origins. Although legal tax regulations are as old as the state, the study of financial law came much later. In Poland, during the difficult period of partitions, the beginnings of the science of tax law showed close relationships with economy. In 1918, when it became possible to freely practice science in the already independent Poland, the scholarly achievements of financial law included a number of books, papers and articles, and there also existed a bunch of professionals educated in financial law. The article contains an overview of the most important publications and organizational structures, in which financial, or fiscal law had been taught until 1918.

${ }^{64}$ H. Radziszewski, Skarb i organizacja władz skarbowych w Królestwie Polskim, t. I: 1815 -1830, Warszawa 1907, t. II: 1831-1867, Warszawa 1908; S. Żółtowski, Die Finanzen des Herzogstums Warschau (1806-1815), t. I-II, Posen 1890-1892.

${ }^{65} \mathrm{~J}$. Bloch, Finanse Rosji w XIX wieku na tle ogólnych dziejów państwa, t. I-III, Warszawa 1883-1884. 


\section{LES DÉBUTS DES SCIENCES JURIDIQUES ET FINANCIÈRES EN POLOGNE (AVANT 1918)}

\section{Résumé}

L'article raconte la naissance de la science du droit financier (fiscal) sur le terrain polonais. Les recherches menées auparavant, concernant son évolution, se sont concentrées uniquement sur la période après 1918, elles faisaient donc abstraction de ses débuts. Bien que la régulation juridique à caractère fiscale soit aussi ancienne que l'État, la science du droit fiscal est bien plus récente. Elle se profile sur le territoire polonais pendant une période difficile, celle de l'occupation des pays voisins envahisseurs et témoigne des rapports étroits avec l'économie, dans le cadre de laquelle elle commence à se développer pour finir par s'en séparer. En 1918, lorsque la pratique devient libre car l'État est indpéndant, les résultats de ce travail de plusieurs années constituent déjà un bon nombre de livres, dissertations et articles sur la science du droit financier. Il existe à l'époque un groupe de spécialistes formés. L'article propose une revue non seulement des publications les plus importantes mais également des structures organisationnelles exploitant la science du droit fiscal avant 1918. 